\title{
Quo vadis, V4? What is the potential of the Czech Republic to promote its interests within the framework of the V4?
}

Keywords: Central Europe, Visegrad Group, EU, the Czech Republic

\begin{abstract}
The original purpose of the Visegrad Group (VG or V4 - which includes Hungary, Poland, the Czech Republic and Slovakia) was primarily to support its member states'accession to the EU and NATO, which it successfully achieved. However, the views on the current cooperation of four Central European countries differ. Some researchers believe that the V4 has transformed since 2004 into a viable project which has become even an inspirational model of cooperation for other regional groupings. According to them, and contrary to doubts about the continuation of the V4 project, membership of the EU has given the V4 a new impulse, and its agenda has been expanded into new areas of cooperation which included EU affairs. Therefore, the V4 operates now as a distinct regional grouping within the EU (i.e. positive input regarding their commitment in several Council presidencies). Others, however, suggest that V4 cooperation seems to be labelled as a defensive project, a coalition within the EU, which is against something (recently the prominent topics have revolved around migration issues) and that it could lead to the marginalisation of the group and thus reduce its importance at the EU level. While discussing the future role of the V4, the article will focus on the Czech Republic, and its
\end{abstract}

* ORCID ID: https://orcid.org/0000-0002-8703-059X, PhD is an Assistant Professor at the Jan Masaryk Centre of International Studies of the University of Economics in Prague, Czech Republic.

** ORCID ID: https://orcid.org/0000-0001-6678-5152, PhD is an Assistant Professor at the Jan Masaryk Centre of International Studies of the University of Economics in Prague, Czech Republic. 
potential to promote its interests within the framework of the V4, especially in the context of its current presidency (from 1 July 2019 to 30 June 2020).

\section{Introduction. V4 Cooperation}

At present, it appears that the Visegrad Group (VG also known as V4) has become a certain symbol and representative of Central Europe (CE) with its ability to facilitate cooperation and coordinate steps of the four countries in international politics. It is obvious that the V4 is trying to assert its interests on the international scene, and the V4 has thus become a forum where individual Central European states can promote their interests. The establishment of the V4 was the first attempt to form a cooperative structure in the post-communist block after 1989 with some potential to cooperate in the field of 'low policy', but also in 'high policy that is relevant to us (areas such as foreign policy and security issues) ${ }^{1}$. The unique goal of the V4 countries as well as group cooperation, was to become a solid part of the West, an area of democracy, stability, security and economic prosperity. Moreover, the establishing of common interests, and an attempt to coordinate its realization was something new in the modern history of this region.

There are certainly many areas of international and security policy where these countries have similar views. The main impetus for the cooperation was the fact that the principal goal of the foreign policy of the V4 states was the inte- grating the European integration structures (namely NATO and EU), which was viewed by these countries as a process with no real political or security alterna- tive. The V4 experience and practice can be used for promoting shared political and security interests at the international, particularly European, level. The aims of the Group are to encourage cooperation with its neighbours, and it officially wishes to contribute to the building of a European security architecture that is based on effective, functionally complementary and mutually reinforcing coop- eration and coordination within existing European and transatlantic institutions. The V4 in this respect supports cooperation between the V4 and other regional groupings (Benelux or the Nordic Council) or with other countries interested in

1 The Declaration on Cooperation between the Czech and Slovak Federal Republic, the Republic of Poland and the Republic of Hungary in Striving for European Integration was signed on 15th February 1991. The fundamental goals beside other things specifically include the full integration into the European political, economic, security and legal systems. The Declaration on Cooperation between the Czech and Slovak Federal Republic, the Republic of Poland and the Republic of Hungary in Striving for European Integration, 1991, http://www. visegradgroup.eu/documents/visegrad-declarations/visegrad-declaration-110412 (23.12.2019). 
such cooperation. The role of the V4 is often underestimated in some respects, or its importance overestimated; however, the V4 has become a part of international policy, and not only that of $\mathrm{CE}^{2}$.

The V4 was one of the tools to facilitate faster accession into the European integration structures. The accession process with the EU was crucial, it was not possible to achieve such an ambitious goal if the countries in $\mathrm{CE}$ were to compete with each other on the international stage. As Bugajski stated:

government officials believed that by banding together and speaking with almost one voice in various multinational formats they were more likely to be heard and no country would fall behind in its aspirations and achievements. ${ }^{3}$

It also caused an intensification of the communication among and between Central European countries. Kořan pointed out that,

there has been a gradual increase of the numbers of V4 meetings, consultations and projects at political, diplomatic bureaucratic and public levels. Also, due to the intensive communication during the pre-accession period, solid communication network among political representatives and diplomatic and bureaucratic actors have been established. ${ }^{4}$

The question was, if after the successful entry into both NATO and the EU in 2004, would the V4 lose its raison d'être. On the contrary it turned out, accession once again intensified dialogue between the countries. The V4 has begun to gather regularly before EU summits and council meetings. The Kroměříž Declaration on cooperation of the V4 countries after their accession to the European Union stated that:

The integration of the V4 countries into the European and Euro-Atlantic structures opens up new opportunities and poses new challenges for their further cooperation on the issues of common interest. ${ }^{5}$

There are certainly reasons to expect that the V4 would have some ambi- tion to do so. Since joining NATO and the EU, the potential of that cooperation

${ }^{2}$ T. Strážay, Neither beautiful nor ugly, but functional: a pragmatic view on the Visegrad Group, «Contemporary European Studies» 2014, No 2, http://www.ces.upol.cz/wp-content/ uploads/2014/07/ces_03_2_2014_Strazay.pdf (23.12.2019).

${ }^{3}$ J. Bugajski, Visegrads Past, Present, and Future, «Hungarian Review» 2011, No. 03, http:// www.hungarianreview.com/article/visegrads_past_present_and_future (23.12.2019).

${ }^{4}$ M. Kořan, The Visegrad Cooperation, Poland, Slovakia and Austria in Czech Foreign Policy, [in:] M. Kořan, (ed.), Czech Foreign Policy in 2007-2009: An Analysis, Prague: Institute of International Relations 2010, p. 117.

5 Declaration of the Prime Ministers of the Czech Republic, the Republic of Hungary, the Republic of Poland and the Slovak Republic on cooperation of the Visegrad Group countries after their accession to the European Union, 2004, http://www.visegradgroup.eu/ documents/visegrad-declarations/visegrad-declaration-110412-1 (23.12.2019). 
platform has not diminished, on the contrary, it has increased since the V4 states have enjoyed full membership rights and therefore also better ability to influence the development of the European continent.

This article deals with the current functioning of the V4 under the Czech Presidency. Its priorities and their achievement are analyzed. It is important to show whether the Czech Republic is able to assert its interests in the V4 and through the V4 in a wider international environment (especially the EU). The aim is to demonstrate, that based on an analysis of the current functioning of the V4, that the Czech Republic has actively exploited the potential of the V4 under the Presidency. The starting point is the characteristics of the V4, especially with regard to its functional design and the potential of V4 actorness.

\section{The Form of V4 Cooperation}

The form of V4 cooperation has remained unchanged in post-accession period, and the Declaration on cooperation of the V4 countries after their accession to the European Union stated that the V4 model would still be based on concrete projects and would maintain its unique "flexible" and open "character". It can be assumed that the development of the V4 will after the EU and NATO acces- sion most probably, "continue to be based on the three widely accepted No's: "no" to institutionalization, "no" to enlargement, and "no" to any slowdown in cooperation"6. In making the V4 more visible and relevant on the international stage, some scholars and policy makers believe that the V4+ mechanism has significant potential. The idea again originated under the Czech Presidency of the V4 in 2007-2008. It has been part of the official V4 agenda ever since. The mechanism is based on the core V4 members, and it involves ad-hoc cooperation with other Central, Eastern, and South-Eastern European countries covering areas such as energy security, EU accession, and the Eastern Partnership 7 .

Since the 1990's, the V4 has established an 'non-institutional' approach to cooperation, which can be considered as one of the main V4 cooperation features to the present day ${ }^{8}$. Until now, the V4 is more of a symbolical group of different

6 T. Strážay, Visegrád - Arrival, Survival, Revival, Bratislava: International Visegrád Fund 2011, http://www.visegradgroup.eu/documents/bibliography/visegradarrival-survival-120628 (23.12.2019).

${ }^{7}$ J. Bugajski, Visegrads Past, Present, and Future, «Hungarian Review» 2011, No. 03, http:// www.hungarianreview.com/article/visegrads_past_present_and_future (23.12.2019).

8 This form of relatively closer but constantly open cooperation has been the result of several factors: complicated and often centrifuges history; bilateral tensions and the lack of mutual trust; partly different geopolitical interests and sensitivities; the different size of the states that result in an asymmetric position in the European political and security 
nations than a coherent political structure with the ability to intervene into the international system ${ }^{9}$. This unique form of governmental cooperation is officially based on:

- rotating one-year presidency, each chairmanship prepares its own presidency programme ensuring, among others, the continuity of the long-term V4 cooperation,

- one official Prime Minister's summit a year at the end of each presidency,

- occasional informal meetings of Prime Ministers (PM) and Foreign Ministers before international events,

- deputy foreign ministers' meetings preceding the PM official summits,

- meetings of other ministers in V4 and V4+ format,

- intensified communication of V4 national co-ordinators and their key role in internal and inter-state co-ordination,

- consultation and co-operation of the Permanent Representations to the EU and NATO in Brussels, as well as in all relevant forums (OSCE, UN, CoE, OECD, WTO, etc.),

- $\quad$ and International Visegrad Fund and its structures. ${ }^{10}$

Other levels of cooperation are meetings between the Presidents of the V4 countries and the cooperation between the Parliaments. Representatives of all countries consider the V4 meetings on different levels - presidents, ministers of foreign affairs and defence, CHODs, political directors, national armaments directors, etc - as periodical. It can be stated that,

these meetings serve well for consultations on many aspects, including information sharing on future plans and solutions realized, but it often depends on the president of the meeting to prevent expert debate to become a meaningless discussion club which unfortunately often happens. ${ }^{11}$

It can be assumed that the intention of the V4 is to preserve its two core principles: „,cooperation not integration”, and, ,instrumentalization not institutionalization" in the future ${ }^{12}$.

system; transitional difficulties with dissimilar impact; insufficient political and economic interest; and last but not least a lack of material and human resources.

9 Cf. A. Lazar, Post-EU-Accession Visegrad Cooperation - Results, Rhetoric, Prospects, «Biztpol Affairs» 2014, pp. 22-44, http://epa.hu/02400/02475/00002/pdf/EPA02475_ BiztpolAffairs_2014_01_022-044.pdf (23.12.2019).

${ }^{10}$ Guidelines on the Future Areas of Visegrád Cooperation, 2004, http://www.visegradgroup. eu/cooperation/guidelines-on-the-future-110412 (23.12.2019).

11 J. Nad', I. Gyarmati, T. Szatkowski, L. Frank, V4 Cooperation and Coordination in Defence and Security, «Defence and Strategy» 2010, No. 2, p. 147, http://www.obranaastrategie.cz/ redakce/tisk.php?lanG=cs\&clanek=47151 (23.12.2019).

12 J. Bugajski, Visegrads Past, Present, and Future... 
On the other hand, the V4 still represents a flexible political instrument for achieving the important of foreign and security policy goals of the states in CE. The 'non-institutionalization' of this cooperation could be advantageous for better adaptability and may provide the ability to swiftly react to the dynamic changing international environment. The experience of the V4 (mainly of turbulent peri- ods during which the group was dysfunctional in 1993-1998) demonstrates that cooperation often dependents on the political will of the leaders from the $\mathrm{CE}$ in the respective countries, and on their willingness to seek consensus.

In addition, the $\mathrm{V} 4$ has a potential to be a functioning regional grouping, however, it does not seem to attract the attention and support from the big European states and its foreign policy elites. Its European partners do not always work in favour of the V4 cohesion, and increasing the political profile of this grouping. $\mathrm{CE}$ is potentially too big and too powerful to support this. These states would rather concentrate on bilateral relations with $\mathrm{CE}$. The $\mathrm{V} 4$ has not yet been able to meet these assumptions in European politics.

\section{The V4 as an actor in international relations?}

The V4 presents itself as a regional actor, but often without having any real political influence and power. This is a specific situation, as it is not fully the result of regional integration, and actorness is all the more probable ${ }^{13}$. Normally, an actor in international relations is considered effective when it is able to influ- ence other actors' behaviour according to its intentions, and when its large-scale aspirations are met by equally large-scale results ${ }^{14}$. The form of cooperation determinates and limits the actorness of the V4 at the same time. In its broad- est definition, actorness is not limited by the existence of stable institutions, the number of units which form the entity, nor by the purpose or motivations of the entity. However, the entity must possess a certain capacity to act, which means to be, "capable of formulating purposes and making decisions, and thus engag- ing in some form of purposive action"15. Furthermore, the action cannot only be autonomous, but also must have an impact on international relations no matter if it reaches the European or global level ${ }^{16}$. The political ability and will of indi-

${ }^{13}$ Cf. E.B. Haas, The Study of Regional Integration: Reflections on the Joy and Anguish of Pretheorizing, «International Organization» 1970, Vol. 24, issue 4, pp. 609-610, https:// www.jstor.org/stable/2706149?seq=1 (23.12.2019).

${ }^{14} \mathrm{Ch}$. Bretherton, J. Vogler, The European Union as a Global Actor, second edition, New York: Routledge 2006, p. 14.

15 Ibidem.

${ }^{16}$ C.A Cosgrove, K.J. Twitchett, The New International Actors: The UN and the EEC, London: Macmillan 1970, p. 12. 
vidually acting countries to cooperate is the prerequisite, but also often the main limitation of successful cooperation. A relevant actor in international relations should be able to formulate coherent policies based on the identification of its goals. Only then, can an actor truly engage in a purposeful action.

Paradoxically, the official reasons that constitute the cooperation of the V4, namely modern history and identical geography (the location of states in the centre of Europe between Germany and Russia) also contribute to some of frictions and political anomalies. These factors then act both as a dividing and unifying elements of the V4 identity ${ }^{17}$. The term CE has in fact traditionally represented a specific fluid geographical unit, where a number of small nations with predominantly different historical experience (with exception of the era of the Cold War) and traditions have co-existed in a common environment. Therefore, the V4 countries may have different foreign policy and security preferences and priorities, or may simply only partly agree about the best policy course. Moreover, CE is not defined exclusively by V418.

The potential for political and security cooperation between the V4 countries remains limited, but it seems to have materialized in the last years into some concrete projects. On the other hand, on several occasions their joint declarations have been inappropriately ambitious compared to the objectively achieved level of the harmonization of their national interests. The development of solidarity and mutual trust between the V4 states is not automatic, and must be created and cultivated by each of the states. The first step is the successful building of trust. Robert Kron said:

First and foremost, they need to create and cultivate a culture of trust, a currency traditionally scarce in the region. And, often, it is the lack of trust that acts as the greatest inhibitor to more robust V4 cooperation. The key here rests with starting small, identifying non-controversial pockets of opportunity where convergence of interests is high and netting small victories that reinforce confidence for larger projects down the line. ${ }^{19}$

These difficulties seems to be reflected also on a European level, where even after ten years the V4 countries are also characterised by, a relatively low influence in Brussels, comparatively small participation in the EU operations and joint initiatives, projects, and programs, and also shortage of representation in

17 M. Schmelzer, Germany and the V4: A Superficial Relationship?, V4 Revue, Prague, Europeum, 2012, http://visegradrevue.eu/germany-and-the-v4-a-superficial-relationship (17.05.2018).

18 T.G. Ash, The Puzzle of Central Europe, «The New York Review of Books» 1999, http:// www.visegradgroup.eu/the-visegrad-book/ash-timothy-garton-the (23.12.2019).

${ }^{19}$ R. Kron, Thoughts on the Visegrád Group: A View from the Potomac, V4 Revue, Prague: Europeum, 2012, http://visegradrevue.eu/?p=656 (17.05.2018). 
European institutions and in NATO structures" 20 . The very loose structure of the V4 de facto means that the political will of the leaders in CE will play a crucial role in the relations within the group and its dynamics ${ }^{21}$. States prefer national interests which can often lead to rivalries between countries. The V4 operates as 'purpose' oriented group. It is evident that the V4 is able to cooperate only if the members perceive it as clearly advantageous, thus co-ordination is only possible in the cases where it suits to all parties 22 .

Therefore, it may quickly move from cooperation to non-cooperation, or even towards competition or conflict. In this case, the Central European states may try to find better partners outside the group, and this individual approach may enable the possibility of gaining an advantage over their other partners, or one of the states having the chance to get more by employing a separate action. Indeed, it is evident that the group shares certain fundamental interests, but also particular states have taken different approaches to specific issues throughout the history of the V4. This type of zero institutionalism and a full dependence on political willingness to reach a consensus could be viewed in fact as the basic determinant and limitation of the V4's actorness in the international arena. Therefore, it can be considered only as a limited international actor, and definitely not as a leader with regards to any matter of international relations. This is not a new situation, throughout the long history of Europe, the CE has been only politically strong on rare occasions. Discussion is often concentrated more on the coordination of policies and the synchronization of steps than the implementation of common projects. The role of the Presidency in this form of cooperation seems to be essential.

\section{The role of the V4 Presidency}

As was mentioned above, the V4's 'strategic' operations are based solely on the principle of periodical meetings of the member states' representatives at all levels (prime ministers, heads of states, ministers, experts, etc.). Official prime ministerial summits take place on an annual basis. Between these official sum-

${ }^{20}$ J. Nad', I. Gyarmati, T. Szatkowski, L. Frank, V4 Cooperation and Coordination in Defence and Security, «Defence and Strategy» 2010, No. 2, p. 145,http://www.obranaastrategie.cz/ redakce/tisk.php?lanG=cs\&clanek=47151 (23.12.2019).

${ }^{21}$ A. Schmidt, Friends forever? The Role of the Visegrad Group and European Integration, «Politics in Central Europe» 2016, No. 3.

${ }^{22}$ H. Gehring, L. Kirchner, Between Common Interests and National Egotism The Role and Potential of the Visegrád Countries in the EU, KAS International Reports 2012, No. 8, p. 74, https://www.kas.de/documents/252038/253252/7_dokument_dok_pdf_31823_1.pdf/ ee346ff3-fa96-1ddd-ca6b-16220f03275d?version=1.0\&t=1539656862433 (23.12.2019); A. Lazar, Post-EU-Accession Visegrad Cooperation ... 
mits - usually in June each year - one of V4 countries holds the presidency over the group. During these twelve months each country prepares its programme and sets several priorities, which it wants to achieve during that period ${ }^{23}$.

The topics are discussed at several levels. The meetings at highest levels are between the Prime Ministers of the V4. They meet at V4 summits and before each European Council meeting in Brussels, and discuss the main areas of interests including the future of the Union, the effective functioning of the Union and its institutions, security policy, EU enlargement and the EU Neighbourhood Policy. Further negotiations are done at a meeting of the state secretaries and departmental directors responsible for coordinating European policies.

The Ministry of Foreign Affairs work with the Office of the Government to coordinate the Czech Presidency especially in EU affairs, EU enlargement and the Eastern Partnership (EaP) matters. The cooperation for sectoral policies are the responsibility of the sectoral ministries, and its results are reviewed at the conclusion of V4 prime ministerial summits 24 .

There are thus presidential prime ministerial summits (eventually with the invitation of other mainly EU partners) and several traditional meetings of foreign ministers (V4 + WB6, V4 + VP, V4 + NB8, spring 2020). Other ministries also organise ministerial meetings. Furthermore, expert meetings with EU and traditional non-EU partners (the USA, Korea, Japan, Israel) are organised as well. There is also cooperation at a parliamentary level.

Due to the non-institutionalized format of V4 cooperation, and the lack of a coherent political structure, the V4 Presidency is among the key tools for an individual country to promote its interests. Each country has the responsibility to prepare a one-year programme and selected the priorities, which are pushed forward via negotiations at meetings at various levels by the political representatives of the country in question. The role of the Presidency is not only to persuade the other V4 countries, and to promote coherence in these matters, but to advocate these goals also at the European level. Success is highly prized, as it may lead to positive repercussions at the European, regional, but also the national level, as these priorities are vital to the national interests of the state. But once again, we must take into account (as it was discussed in the sections above) the limits of V4 cooperation, and its rather weak position as an actor in IR. Both factors make this task (the promotion of its national interests at regional and European level) extremely difficult. In the following part, we will examine the program

${ }^{23}$ Presidency Programs, Visegrad group, http://www.visegradgroup.eu/documents/presidencyprograms (23.12.2019).

24 Programme for the Czech Presidency of the Visegrad Group, Ministry of Foreign Affairs, 2019, https://www.mzv.cz/public/ea/a/f7/1540281_1338971_program_V4_e_brozura_A4_ EN.pdf (23.12.2019). 
and the main activities of the Czech Republic during its V4 Presidency, which started at the beginning of July 2019. It is the $8^{\text {th }}$ Czech V4 Presidency since the establishment of the Group.

The last Czech V4 Presidency was held between July 2015 and June 2016. It was a very complicated period not only in the V4's history, but for the EU as whole. Several crises had hit Europe and the world, including the Arab Spring, the continuous debt crisis and the peak of the migration crisis. The multiple geopolitical stresses contributed to a divergence between the V4 countries, but the Group still remained an important platform for debating differences ${ }^{25}$.

The motto of the Presidency was V4 Trust (also read as We for trust) which stressed a shared trust between the four members. This slogan summed up the quality that the countries consider to be the most important added value of V4 cooperation (given the lack of institutional background): a unique level of mutual trust based on functional, close relationships and an open exchange of views between partners, who may not always agree on everything 26 .

Above all, the main aim of the Czech Republic was to show that the V4 remained the basic and key format for cooperation in $\mathrm{CE}$, especially at a time when, in addition to long-term planned activities, it was necessary to respond more and more to ad hoc and newly formed situations in the EU and its neighbourhood. Therefore, the priorities during the Czech V4 presidency program were framed by the need to increase the V4's togetherness and internal cohesion. The main objectives were situated in the areas of security and defence (namely the establishment of a V4 Battle Group), the European Neighbourhood Policy (especially due to aggressive Russian behaviour in Eastern Ukraine) and South-eastern countries' Energy Policy. In reality and due to the circumstances, the most visible agenda of the second half of the year was the growing influx of immigrants ${ }^{27}$ which also heavily influenced the high-level meetings and their program.

Already at the beginning of the Presidency the selected priorities were judged as being rather ambitious considering the turbulent environment in which they were to have been fulfilled. But it was mostly the migration crisis that prevented the Czech Republic from concentrating on the priorities, as the main goal seemed to be to effect damage control, and to soften the rift between the older and newer member states. Unfortunately, the activities of the Czech Republic in this regard

\footnotetext{
${ }^{25}$ M. Kořan et al., V4 Trust - the Czech Presidency of the Visegrad Group (2015-2016), Think Visegrad Mid-Term Review, February 2016, https://think.visegradfund.org/wp-content/ uploads/Think-Visegrad_Czech-V4-Presidency-Mid-term-review.pdf (25.12.2019).

${ }^{26}$ Programme for the Czech Presidency of the Visegrad Group 2015-2016, Ministry of Foreign Affairs, 2015, https://www.mzv.cz/public/ea/a/f7/1540281_1338971_program_ V4_e_brozura_A4_EN.pdf (23.12.2019).

${ }^{27}$ Ibidem.
} 
proved to be unsuccessful. The image of the V4 deteriorated seriously due to the reluctance of the V4 countries to accept their redistribution quotas as part of the solution of the migration crisis. Although an increasing number of EU members shared a similar scepticism, the V4 as the whole started to be perceived as a coalition known for obstructing practices 28 .

\section{The current V4 Presidency of the Czech Republic}

Four years later, in July 2019, the Czech Republic has again assumed the V4 Presidency. The time has been less turbulent, but several challenges have remained. The EU has just entered a new institutional cycle with new leaders. Soon, the 2021-2027 Multiannual Financial Framework will be finalised. Moreover, the Union will deal with the consequences of the expected Brexit as well as various reforms to common policies, namely related to migration and asylum or security.

Therefore, the Czech representatives have stated that they have chosen a rational, pragmatic and constructive approach in order to deal with the challenges that Europe currently faces - these challenges threaten its stability, including its neighbours and its own security. More than before, the openness to other European partners is discussed in order to enhance the coalitions potential within the Union 29 .

The program of the V4 presidency has been presented under the motto 'V4Reasonable Europe' and is divided into three thematic areas:

\section{Reasonable solutions}

The first area is presented as V4 for a Rational Europe, and is linked to Eastern Partnership countries, defence cooperation, and internal relations within the V4. The key objective is to coordinate and to promote the position of V4 in the process of defining the future priorities of the Union's economic and social policies, while fully respecting the fundamental principles of the Member States' social security systems and the financial equilibrium. The Czech Presidency seeks to deepen the EU internal market and preserve its four freedoms (the need to eliminate all remaining barriers); to strengthen economic and social convergence in the EU; to support the European integration of the Western Balkan countries, and the pro-European orientation of the Eastern Partnership countries (support of the economic and political

${ }^{28}$ M. Kořan et al., V4 Trust...

${ }^{29}$ Programme for the Czech Presidency of the Visegrad Group, Ministry of Foreign Affairs, 2019, https://www.mzv.cz/public/ea/a/f7/1540281_1338971_program_V4_e_brozura_A4_ EN.pdf (23.12.2019). 
reforms); to enhance the position of the V4 within NATO and the EU, and to reinforce the NATO-EU cooperation (the V4 EU Battlegroup was on standby in the $2^{\text {nd }}$ half of 2019); finally to promote internal relations within the V4, including the activities of the International Visegrad Fund ${ }^{30}$.

2. Revolutionary technologies - innovative economics and its social impacts:

As a second priority area, the Czech Presidency focuses on support for research, development and innovation (i.e. innovative business and smart investments). The country also supports innovative ecosystems (especially startups and scale-ups) and capital markets to increase investment in innovation,

knowledge transfer and research-business linkages. Among the priorities, there is also the development of the Digital Single Market, especially the elimination of barriers and administrative burdens for businesses, cross-border digital infrastructures and e-government. The significant topics are artificial intelligence (AI), the free movement of data, or the concept of integrated city management, the so-called Smart Cities concept, and finally a sufficient labour supply and the prospects for labour in a time of technological change ${ }^{31}$.

3. Reconciling approaches

The final objective is to overcome the dividing lines and strengthen mutual coherence within each V4 society, within the V4 as a group and within the EU as whole. Moreover, the Czech Republic supports V4 + cooperation to expand the V4 potential for forming coalitions, especially with key EU partners such as Germany, France, Austria, Benelux, the Nordic and Baltic States. The topics to be discussed are the new EU institutional cycle; the final negotiations of the future EU Multiannual Financial Framework; the future of the EU's migration and asylum policy; regional cooperation on connecting transport infrastructure and energy policy (especially nuclear energy).

The priorities on which the Czech Republic focuses during the V4 Presidency are, as it was manifested, not only to strengthen the coherence within the group, but they also need to be promoted at the European level. Due to the rather negative image of the V4 in the EU, especially in some countries (France, Belgium, etc.), it has become clear that the Group should search for partners outside this platform ${ }^{32}$. The position of the Czech Republic is even more crucial because of the formation of the new European Commission and the election of the new

\footnotetext{
30 Programme for the Czech Presidency of the Visegrad Group, Ministry of Foreign Affairs, 2019, https://www.mzv.cz/public/ea/a/f7/1540281_1338971_program_V4_e_brozura_A4_ EN.pdf (23.12.2019).

${ }^{31}$ Ibidem.

${ }^{32}$ ČR chce zvyšovat koaliční potenciál V4 v EU, České noviny, 18.7.2019, https://www. ceskenoviny.cz/zpravy/cr-chce-zvysovat-koalicni-potencial-v4-v-eu/1778648 (03.01.2020).
} 
President of the European Council. In order to investigate the potential of the Czech Republic to promote its interests within the framework of the V4 in the context of its current presidency, we will examine in more detail the three goals that form a key part of the Czech agenda, and play a significant role in discussions at a regional as well as the European level: (1) the completion of single market, (2) support of EU enlargement and EaP, and (3) defence cooperation.

\section{The V4 and single market}

One of the key priorities is the deepening of the internal market. According to the Czech program, the deepening of the internal market should lead to economic and social convergence within the EU and, geographically, the convergence effect should also be visible in the countries directly neighbouring with the EU (in particular the Western Balkan countries and the Eastern Partnership countries). Here, the long-term interests and objectives of the V4 are intertwined with the interests that the member states of this group try to promote within the EU. These includes particularly the free movement of people (mainly the movement of workers), the free movement of goods and the related problem of dual food quality, cooperation in border areas within the EU, and cooperation with EU neighbours (especially in the Western Balkans and Eastern Partnership countries).

From a long-term perspective, this priority is linked not only to the activities of the V4, but also to the Czech Republics' domestic and foreign policy goals (e.g. the Bucharest meeting in May 2019 showed interest in the development of the EU internal market). The Czech Republic's efforts to draw attention to the need for internal market reform fittingly responds to changes that can be observed in the negotiations and decision-making within the EU institutions ${ }^{33}$. In this regard, the efforts to strengthen the internal market in terms of industry and trade are similar to those stated in the EU Council document entitled: The EU industrial policy strategy: a vision for $2030^{34}$, which refers to the need for a fully functioning and harmonized internal market. It is also connected to the opinion of the European Economic and Social Committee (EESC) which advocates the need to harmonized standards that increase transparency and legal certainty within the EU single market and thus lead to its completion. In general, it is a response

${ }^{33}$ H. Bauerová et al., Scénáře budoucího vývoje jednotného trhu EU v kontextu českého předsednictví V4: reforma vnitřniho trhu a možni partneři, Policy Brief, Ministry of Foreign Affairs of the Czech Republic 2019.

${ }^{34}$ An EU Industrial Policy Strategy: a Vision for 2030, Council of EU, 2019, https://www. consilium.europa.eu/en/press/press-releases/2019/05/27/council-calls-for-a-comprehensivelong-term-industrial-policy-strategy-with-a-vision-for-2030 (23.12.2019). 
from the EESC to the European Commission (EC) Communication issued in November $2018^{35}$.

It is this EC Communication which has such potential for the Czech proposals and arguments. This priority seems to be in accordance with the interests of the EC and therefore its practical feasibility may seem more probable. In its Communication, the European Commission responds to documents issued in the recent past - namely the Capital Markets Union and the Digital Market Strategy ${ }^{36}$, which foresee changes to the internal market in the future. In its most recent communication (November 2018), the European Commission discusses the advantages but also the weaknesses of the common European market. Inconsistencies and the insufficient enforcement of the common rules of the internal market are the most problematic issues. Moreover, there is also a reference to inconsistency in taxation and different social rules. As a solution to the problem, the European Commission proposes a dialogue at the highest political level which should overcome national specificities and lead to the creation of a set of uniform rules. The EC Communication does not directly mention different quality of food (as it is also stressed by the V4 countries), but it does mention the non-compliance of EU law with the rules applied in Member States, e.g. on food products or workplace health and safety regulations. In general, the EC Communication mentions food (quality, uniform consumer-friendly labelling) in a relatively long text ${ }^{37}$. This brings the interests of the EC and of the Czech Republic as well as of its V4 partners closer. It can therefore be stated that at this point the interests of consumers are a common denominator of the EC and the Czech Republic's policy statement.

Another area where the Czech Republic pursues similar interests as the EC is the cross-border mobility of workers and the need for cooperation between states in this area, especially in terms of protecting workers' rights and setting dispute resolution rules between public authorities. The EC wants to set up a European Employment Affairs Authority to deal with these problems.

The Czech Republic also emphasizes the development of the digital mar- ket with the help of artificial intelligence. The basis for the Czech position is a joint paper of V4 countries on artificial intelligence, issued in April 201938

${ }^{35}$ Communication from the Commission. The Single Market in a changing world. Euro- pean Commission, 22.11.2018, https://eur-lex.europa.eu/legal-content/EN/TXT/?uri= CELEX:52018DC0772 (23.12.2019).

36 Action plan on building a capital markets union, European Commission, 2015 https:// ec.europa.eu/info/business-economy-euro/growth-and-investment/capital-markets-union/ capital-markets-union-action-plan_en (24.07.2019).

${ }^{37} \mathrm{H}$. Bauerová et al., Scénáre budoucího vývoje jednotného trhu EU v kontextu českého predsednictvi $V 4 \ldots$

38 Visegrad 4 countries' thoughts on the Artificial Intelligence and maximising its benefits ahead of release of the European Commission's Communication on the topic, Visegrad 
in response to the EU Coordinated Plan on Artificial Intelligence published in December $2018^{39}$ and the National Strategy for Artificial Intelligence ${ }^{40}$. Cooperation between countries is crucial in the context of the development and functioning of the digital market. Therefore, the Czech Republic places the main emphasis on joint activities within the framework of cross-border cooperation, predominantly at the V4 level. The Czech Republic also has also organized a conference on artificial intelligence, with the aim of connecting researchers and making itself visible among Member States. The digitization of the internal market is one of the points in the EC Communication, which combines digitization with greater efficiency on the internal market. Although the link between digitization and artificial intelligence is not explicitly mentioned in the EC document, it might be seen as a tool to improve the existing and newly proposed mechanisms for the functioning of the internal market. The promotion of such a proposal is not unrealistic, but it requires clear support from other Member States, not just the V4 platform. The search for partners in the reform of the internal market may be potentially problematic as has been recently demonstrated by the rather unsuccessful implementation of the Strategy for Single Market of Goods and Services ${ }^{41}$ in $2015^{42}$.

In terms of the promotion of the Czech Republic's interests that are linked to the internal market, two levels need to be applied. The first level is the interest of the EU institutions. This is undeniable and results from the latest documents issued by the EC. EU institutions are interested in reforms that deepen and com- plete the internal market. The cooperation with EU Member States is the second key level in promoting its interests. The Commission wants to give the Member States some space to influence the new internal market rules. The strategy iden- tifies political dialogue between countries as the tool for finding the necessary consensus, which will underpin the changes in the internal market in the future. At the same time, the EC is aware of the sensitivity of the topics discussed, which are often dealt with individually at national level. Here, the Czech Repub- lic should use the potential arising from the interests contained in the Program

group, April 2018, https://slord.sk/buxus/docs//PODUJATIA/V4_thoughts_on_the_

Artificial_Intelligence_and_maximising_its_benefits.pdf (23.12.2019).

${ }^{39}$ Coordinated Plan on Artificial Intelligence (COM (2018) 795 final), European Commission, 7.12.2018, https://ec.europa.eu/knowledge4policy/publication/coordinated-plan-artificialintelligence-com2018-795-final_en (19.12.2019).

40 National Artificial Intelligence Strategy of the Czech Republic, Ministry of Trade and Industry, 2019, https://www.mpo.cz/assets/en/guidepost/for-the-media/press-releases/2019/5/ NAIS_eng_web.pdf (27.12.2019).

${ }^{41}$ A deeper and fairer Single Market. New opportunities for business and people, European Commission, 2015, http://www.europarl.europa.eu/RegData/etudes/BRIE/2015/573873/ EPRS_BRI(2015)573873_EN.pdf (27.12.2019).

${ }^{42} \mathrm{H}$. Bauerová et al., Scénáre budoucího vývoje jednotného trhu EU v kontextu českého predsednictví V4... 
Statement and seek suitable partners to support its interests, coming not only from the CE.

In terms of cooperation with other countries, it is necessary to perceive primarily the effort to coordinate within the V4, which is logical. But here too, certain limits may be expected, as the outcome of the V4 negotiations is not bind- ing on states. It is also important to consider the V4+ cooperation format, where the Czech Republic mentions Germany, France, Austria, the Nordic and Baltic States and the UK as priories. Within the framework of cooperation in the field of the labour market, the Czech Republic counts on the V4 + Germany format, which is built on bilateral cooperation within the framework of the Czech-German Strategic Dialogue. Moreover, cooperation with Austria and Germany has already taken place in partial segments of the internal market, and it also exists among energy regulators (in the form of cross-border cooperation).

In the case of Austria and Slovakia it is necessary to positively perceive the so-called Slavkov format of negotiations, which is also debating the topics of the Czech program. On the other hand, this can potentially cause conflict within the V4 because it does not include all V4 members.

Potential partners to promote internal market reform are many, but they have different views on the form of the reform. Deeper integration (completion) of the internal market is supported by Estonia, Denmark, Finland, France (these countries share, however, also supranationalist tendencies), Ireland, Croatia, Latvia, the Netherlands, Slovakia. The completion of the common market of services is promoted by Belgium or Estonia. Digital Single Market (Artificial Intelligence) is also supported by Belgium, Estonia, Denmark, Finland, France, Croatia, Ireland, Cyprus, Latvia, Germany, Slovakia. The priority of linking to consumer protection and fighting against the dual quality of goods is shared by France, Slovakia and Hungary. Support of science, research and innovation is shared by Germany, France, Cyprus, Latvia, Sweden, Denmark and Slovakia ${ }^{43}$.

On the other hand, it is possible to find states that cannot be considered as partners in some areas: social policy is seen differently by Belgium, Denmark, Finland, France, Luxembourg, Spain or Slovakia (as their aim is the introduction of the European wage). Freedom to provide services is viewed differently by Hungary and Poland. Also, Italy, Spain and Belgium have different recommendations for the reform of the internal market. Finally, there is also a third group of countries where their position is difficult to predict, and thus their cooperation cannot be excluded or confirmed (i.e. Romania, Greece, Portugal).

\footnotetext{
${ }^{43} \mathrm{H}$. Bauerová et al., Scénáře budoucího vývoje jednotného trhu EU v kontextu českého predsednictví V4...
} 
From this short analysis, we can form a group of like-minded states (of a similar size to the Czech Republic) that wish to pursue the same or very similar objectives in completing the internal market: Denmark, Estonia, Finland, Croatia, Ireland, Latvia and the Netherlands. Interestingly, the only V4 country that we can add to this group is Slovakia. On the other hand, it is hardly possible to include Hungary and Poland, who refused for instance to accept the directive on the posting of workers abroad last year. In this context, it is thus necessary to pursue intensive V4 negotiations that may lead to consensus or compromise.

A group of states, which cannot be considered as partners, are countries in favour of supranationalist changes in building the internal market, such as Belgium, Denmark, Finland, France, Luxembourg or Spain. In addition, there are countries that pursue very specific internal market objectives, for instance in the context of migration policy, such as Spain, Greece and Italy.

\section{V4 and EU enlargement and the EaP}

Both issues (EU enlargement and the EaP) are high on the agenda of all V4 countries. Unlike the reform of the internal market, there is an internal con- sensus among the V4 states. In the V4 Statement on the Western Balkans (Sep- tember 2019),

they reiterated their unequivocal support for the EU accession of the Western Balkans and their firm belief that the reunification of Europe cannot be complete without them joining the European Union. They also underlined that the EU enlargement policy provides an invaluable tool for achieving security, stability, and prosperity in the Western Balkans...44

In a similar manner, in a Joint Statement on 10th Anniversary of the Eastern Partnership (May 2019) the V4 countries also,

underlined the importance of keeping the Eastern Partnership high on the EU's agenda and reaffirmed the mutual interest to continue this unique policy of the European Neighbourhood based on shared fundamental values and the common commitment to the principles of international law, human rights and democracy, rule of law, accountability and good governance, sustainable development and the market economy. Political association and economic integration of the Eastern partners with the EU remains the main goal of the program. ${ }^{45}$

44 V4 Statement on the Western Balkans, Visegrad Group, 12.9.2019, http://www. visegradgroup.eu/documents/official-statements/v4-statement-on-the-190912 (23.12.2019).

45 Joint Statement on the Eastern Partnership of the Foreign Ministers of the Visegrad Group, Visegrad Group, 12.4.2017, http://www.visegradgroup.eu/calendar/selected-events- in2017-170203/joint-statement-on-the-180227 (03.01.2020). 
Unfortunately, it seems at that this time it has been rather difficult to find potential partners among other EU member states, or EU institutions.

Although the new EC President, Ursula von der Leyen, confirmed the perspective of the Western Balkans, the attention paid to this area has decreased in recent years and this trend is followed in many respects by the new Commission (and it is also manifested by the French refusal to open negotiations with North Macedonia and Albania). The reactions coming from the Balkan countries are not optimistic either. Stronger nationalist and populist voices have gained more space, and in particular tensions between Serbia and Kosovo may escalate in the near future.

The situation linked to the Eastern Partnership Initiative is even more complicated. It was the then Czech EU presidency that together with Poland and Sweden that brought the EaP to life after a similar French initiative for the Mediterranean region in May 2009. The EaP emerged as a counterweight to the Union for the Mediterranean with the aim of differentiating between 'European neighbours' and 'neighbours of Europe', as famously delineated by the former Polish for- eign minister Radek Sikorski ${ }^{46}$. In 2014, it was the illegal Russian annexation of Ukraine's Crimea and the City of Sevastopol as well as aggression in the East of Ukraine, which dragged Eastern Europe into the chaos and instability that persists until today.

The last couple of years of the EaP can be generally described as a process of squaring the circle of matching different expectations of partner countries with the possibilities on the EU's side ${ }^{47}$. This is most notably connected to the issue of the future membership of the EU, but also to general willingness of EU Member States to commit to stronger integration with their Eastern partners. In addition, we can observe an increasing tendency of 'EaP-fatigue' that are accompanied by pro-Russian sentiments of some of the EU Member States, which does not help to move mutual relations forward ${ }^{48}$. From the group of six countries, only Georgia, Moldova and Ukraine have signed an association agreement and a free trade agreement. The Eastern Partnership seems thus to be rather marginalized.

Indeed, it is apparent that the EU interest in the EaP region has declined over the last few years ${ }^{49}$. And the way the topic has been so far discussed by von der Leyen does not suggest any changes. The new Commission President, for

46 P. Havlíček, 10 Years of Eastern Partnership. From Prague to Brussels and How to Proceed, AMO 2019, http://www.amo.cz/wp-content/uploads/2019/09/10-Years-of-Eastern-PartnershipFrom-Prague-to-Brussels-and-How-to-Proceed_AMO_1_23_9.pdf (05.01.2020).

47 Ibidem.

48 Ibidem.

49 The Union did not even organize a larger summit at the highest level, despite the fact that the EaP initiative celebrated its 10th anniversary in 2019. 
instance, did not mention the countries that are part of the Eastern Partnership in her Agenda ${ }^{50}$. An important signal has also been the election of a new Commissioner for the neighbourhood agenda. Although it might seem that the allocation of this portfolio to the V4 group, which generally supports South and East integration, is an encouragement for the Eastern Partnership states, the appointment of Várhelyi was criticised in the context of complicated relationship between Hungary and Ukraine (over the Ukrainian Minority Languages Act). Even the comments of the High Representative of Foreign and Security Policy Josep Borrell did not raise much optimism ${ }^{51}$. Although he stated that the Eastern Partnership belonged among the EU's priorities, he mentioned it in connection with the current threats coming from Eastern Europe, with the need to control and ensure the stability of the EU's borders and the strengthening of the resilience of the Union's partners ${ }^{52}$.

A positive signal can be the fact that the agenda of the enlargement and EaP has remained part of the specialized Directorate-General (DG NEAR) and was not merged with the Directorate-General for International Cooperation and Development (DG DEVCO). Further negotiations related to the financial instrument designed for EU programs and activities in neighbouring countries will now be crucial. It is still possible that the formerly separate Neighbourhood Instrument (ENI) will be removed from the broad Neighbourhood and Development and International Cooperation Instrument (NDICI).

\section{The V4 and defence}

Security and defence have always been among the key issues for the postcommunist countries of CE. At the beginning of the 1990's the main concern was to prevent the emergence of a security vacuum in the region. It was a lesson learned from the interwar period. Not long after the formation of the V4, the member countries tried to develop defence cooperation ${ }^{53}$. The cooperation was

${ }^{50} \mathrm{U}$. von der Leyen, A Union that strives for more. My agenda for Europe, Political guidelines for the next European Commission 2019-2024, 2019, https://ec.europa.eu/commission/sites/ beta-political/files/political-guidelines-next-commission_en.pdf (03.01.2020).

51 Hearing with High Representative/Vice President-designate Josep Borrell, 7.10.2019, https://www.europarl.europa.eu/news/en/press-room/20190926IPR62260/hearing-withhigh-representative-vice-president-designate-josep-borrell (05.01.2020).

52 The perception of the region is thus very closely linked to the basic ideas of the European Global Strategy: Shared Vision, Common Action: A Stronger Europe. A Global Strategy for the European Union's Foreign And Security Policy, EEAS, June 2016, http://eeas.europa. eu/archives/docs/top_stories/pdf/eugs_review_web.pdf (04.01.2020).

${ }^{53}$ Defence Cooperation of the V4+, Pražský studentský summit, AMO, 2014. 
easier for obvious reasons: the armament of the V4 armies were almost identical given their former membership of the Warsaw pact. This former experience was not the only converging element, as the discussions focused also on the modernization of their armaments.

Nevertheless, the primary aim of the countries was to become a member of NATO and of the European structures. This meant that many discussions and interactions between the states in area the military and defence did not fully utilize the potential as the planned projects failed. The entire cooperation was therefore at that time based mainly on the political consultations. The situation partly changed after the invitation of the Czech Republic, Hungary and Poland to the structures of NATO in 1997. The willingness to accelerate the Slovak integration led to more effective consultations on defence and security issues among the V4 countries $^{54}$. But after the accession of Slovakia to NATO in 2004, V4 military and defence cooperation decreased once again and returned to be focused on political consultations.

Another revival of a deeper form cooperation started in 2010, in the middle of the financial crisis, which led to the creation of new formats of cooperation in the defence area. NATO launched its smart defence initiative and at the same time the EU Pooling and Sharing was introduced. The V4 countries first concentrated on the idea of strengthening the ties between $\mathrm{CE}$ and Euro-Atlantic structures. Therefore in 2012, before the NATO Chicago summit, they committed to, "promote regional and Euro-Atlantic security by strengthening their political commitment and enhancing defence capabilities" in the declaration called Responsibility for a Strong NATO55.

These first steps led later to the approval of strategic documents that gave the V4 stronger foundations and better structure. First, the V4 countries signed a document entitled: Long Term Vision of the Visegrad Countries on Deepen- ing their Defence Cooperation ${ }^{56}$. The document was signed in 2014 during the Hungarian V4 presidency. More importantly the V4 soon signed and specified areas of defence and security cooperation in the Action Plan of the V4 Defence Cooperation ${ }^{57}$. The document planned cooperation in the areas, such as the V4 EU Battlegroup, Defence Planning Cooperation, Joint Training and Exercises, Joint Procurement and Defence Industry, Military Education, Joint Airspace Protection, Coordination of Positions or Communication Strategy 58 .

\footnotetext{
${ }^{54}$ Ibidem.

${ }^{55}$ Defence Cooperation of the V4+, Pražský studentský summit, AMO 2014.

${ }^{56}$ Long Term Vision of the Visegrad Countries on Deepening their Defence Cooperation,

Visegrad group, 12.3.2014.

${ }^{57}$ Action Plan of the V4 Defence Cooperation, Visegrad Group, 2014.

58 Ibidem.
} 
One of the key results was the joint V4 EU Battlegroup. At first, the new members of EU were not experienced in the creation of Battlegroups. Their first formations of Battlegroups were thus established with the already experienced EU members individually: Hungary cooperated with Slovenia and Italy in 2007. Poland and Slovakia formed a Battlegroup together with Germany, Latvia and Lithuania in 2010. Only later after gaining experience, did the countries of the V4 agreed to create of their own V4 EU Battlegroup ${ }^{59}$. The idea of creating a Joint V4 EU Battlegroup started in 2011 and the V4 countries agreed to form it by the year 2016. This Battlegroup should be able to deploy within 10 days and within a radius of $6000 \mathrm{~km}$ from Brussels ${ }^{60}$.

Cooperation in security and defence has been one of the key priorities of the Czech Republic for years. Already during the Czech presidency in 2015/2016, the V4 continued with building a, "permanent V4 military structure" in accordance to the Long-Term Vision. The Czech political representatives also promoted the harmonization of the national defence with NATO and the rest of the EU. A series of consultations about defence took place, especially before the Warsaw Summit in 2016. Moreover, during the Czech Presidency the first V4 EU Battlegroup came to stand-by. This Battlegroup was the same way as other Battlegroups, "available for rapid deployment within ten days and within a radius of six thou- sand kilometres from Brussels"61. Emphasis was also put on planning of some other possible areas of cooperation, such as joint airspace protection. Special attention was paid to the V4 within the structures of NATO, and the implementa- tion of the Readiness Action Plan (RAP).

Similar priorities were introduced by the Czech Republic in July 2019 at the beginning of its current V4 Presidency. The Czech program identified several aims that seek to promote the internal coherence between V4 countries. These include a Strategic Review of V4 Defence Cooperation, which should launch an open discussion on the development of the security environment and update the 'Longterm Vision of the V4 Countries' in order to strengthen their defence cooperation. Another goal is to harmonize the defence plans of the V4. In addi- tion, the V4 countries should also coordinate their positions on defence planning and capabilities development in advance of meetings in broader NATO and EU forums as well as in relation to their partners, especially Germany. Other priorities support the strengthening of the harmonization in human resource management,

\footnotetext{
${ }^{59}$ Great importance for V4 members as well as for all other EU countries was to enhance the interoperability of the respective armies and their equipment in order to be able to cooperate without significant difficulties. The interoperability was to be done according to the NATO norms.

${ }^{60}$ Defence Cooperation of the V4+, Pražský studentský summit, AMO 2014.

${ }^{61}$ Ibidem.
} 
training and education as a means of enhancing the interoperability of the Armed Forces $^{62}$ or, potentially, include a search for opportunities for joint V4 operational deployment, building on its own positive experience of operational deployments abroad.

These key priorities touch on the cooperation of the V4 countries with NATO and the EU which has been for all four countries the main defence platforms since the 1990's. These are the priorities where the consensus has been maintained. The Czech Republic thus promote the development of a common V4 expert and political position on the harmonisation of the NATO Defence Planning Process, and EU defence initiatives. It explores the opportunities for a possible joint V4 permanent structured cooperation (PESCO) capabilities development project and examines the opportunity for V4 cooperation within the framework of the European Defence Fund. It also coincides with commitment to create multinational battle groups, in line with NATO and EU activities. The V4 EU Battlegroup (V4 EU BG) was ready for its standby period again during the Czech V4 Presi- dency in the second half of 2019. Moreover, the Czech Presidency advocates the building of the battlegroup again in 2023. The priority is to create a V4 EU BG modular structure with a 1-year standby and 4-year rotation. Ministers also talked about activities under PESCO, the rotation of soldiers in some foreign operations, especially in the Baltic and Sahel countries, or joint exercises. In October 2019, for example, an exercise called CZECH LION took place with 800 soldiers from V4 Armies (ground forces), or a COOPSEC 2019 exercise which aimed at strengthening and protecting the external borders ${ }^{63}$.

One of the other aims of the Czech presidency was to deepen defence cooperation in the form of V4+, mainly with Germany, France or the United Kingdom. The Czech presidency also supported the strengthening of ties between the V4 and Nordic Defence Cooperation (NORDEFCO) or the Central European Defence Cooperation (CEDC) initiative ${ }^{64}$.

Therefore, the cooperation in the area of defence and security seems to have the highest potential. It does not only belong among the priorities of the foreign and security policy of the Czech Republic, but it shows progress and deeper coherence among the V4 countries, unlike the differing stances of the V4 coun-

${ }^{62}$ Sharing information and experience is also important. For example, on armaments. The Czech Republic has previously allowed Hungary to license the production of short firearms by Česká zbrojovka Uherský Brod during extensive rearmament of the local armed forces. Now it is possible to offer 3D short-range radar from Retio, or subsonic L-39 NG aircraft from Aero Vodochody. M. Šiška, Předsednictvi ČR zemí V4: jednotný postup v rámci NATO a EU, «CZDefence» 24.6.2019, https://www.czdefence.cz/clanek/predsednictvi-cr-zemi-v4jednotny-postup-v-ramci-nato-a-eu (05.01.2020).

${ }^{63} \mathrm{M}$. Šiška, Předsednictvi $\check{C} R$ zemí V4....

${ }^{64}$ Ibidem. 
tries with regards to the internal market or the difficulty to push forward the topic of the EU enlargement and Eastern Partnership at the European level.

\section{Conclusion}

The cooperation of the V4 has already been a reality for almost three decades. The four countries were brought closer together by the primary goal to join the Western European structures (the EU and NATO). Although these goals were fulfilled upon entry to the EU, their cooperation did not cease to exist, as some predicted. On the contrary, the V4 countries realized that effective cooperation and coordination may help them to pursue their goals also at the European level. After 2004 the V4 presented itself as the representative of regional interests and,

reacted to the new European challenges, e.g. entrance into the Schengen system or full integration into the domestic market. The Kroměriž declaration formed the basis for the further activities of the Visegrad Group. ${ }^{65}$

Since the beginning of its establishment the V4 has represented a rather flexible political instrument for reaching important goals of foreign and security policy of the states in CE. This flexibility, which among other things, means the 'non-institutionalization' of its cooperation, which could be advantageous as it could be more adaptable and so have the ability to react swiftly to the changing international environment. On the other hand, the very loose structure of the V4 de facto means that the political will of the leaders in CE plays a crucial role in the relations within the group and its dynamics. States prefer their own national interests, which can often lead to rivalries between the countries of the V4. The V4 thus operates as 'purpose' oriented group, and it is able to cooperate only if the members perceive it as clearly advantageous, and only in cases where it suits to all parties.

Apart from the V4 internal coherence, its role in the EU should be considered. The form of it cooperation determinates and limits the actorness of V4 at the same time. Moreover, it was the passive stance of the four states towards the influx of immigrants in 2016 and, especially their refusal of the quota system which complicated the V4's already unstable position, with the V4 labelling itself as a defensive project: a coalition within the EU which is against something. Unfortunately, the V4 has not been able to repair this rather negative image since 2015, and this acts as an hindrance to all the other efforts of the V4, and therfore this must be

${ }^{65}$ H. Bauerová, The V4 and European Integration, «Politics in Central Europe» 2018, Vol. 14, issue 2, pp. 121-139. 
counted as a factor when analysing the possible impact of the V4 Presidency. The V4 presents itself as a player, but often without having real political power.

Despite all these circumstances, the V4 Presidency is still a significant tool to promote a state's national interests among a group of partners. The one-year program is discussed among the members at different levels and each country may choose several priorities which are of key national interest. If successful, the goals are accepted by the rest of the countries, and the consensus within the Group is ensured, and the issue is promoted also at the European level. An example may be their entry into the Schengen system after 2004. Later, the V4 countries concentrated on the area of European foreign policy, energy security or defence cooperation. It usually touches on the spheres in which all states have shared interests.

The study shows that there are three long-term priorities at the national level that the Czech Republic has especially attempted to promote at the regional as well as at the European level. These concern mainly the reform of the EU internal market, the strengthening of defence cooperation and the relations with the Eastern and Western Balkan countries. While analysing the ability of the Czech Republic to promote each priority individually within the V4, and there potential impact on the European level, we can see that such task is often rather difficult. First, there are divergent views within the internal market among the V4 members, but the Czech Republic might be able to secure support from other likeminded states (such as Denmark, Estonia, Finland, Croatia, Ireland, Latvia and the Netherlands). Vis-à-vis EU enlargement and EaP the V4 countries are mostly in agreement, except for Hungarian-Ukrainian relations, which has deteriorated in recent months. Unfortunately, the consensus within the V4 is accompanied with a lack of support from other Member States, especially large ones (namely France). Moreover, the Commission (contrary to the internal market) also lacks interest in this subject. It thus seems that the greatest potential lies in promoting defence cooperation, where there has been progress within the V4 (i.e. the V4 EU Battlegroups), and also a willingness to cooperate at the European level, both within the Common defence and security policy (despite the primary reluctance of Poland to engage in PESCO) and NATO.

To conclude, the potential of political and security cooperation of the V4 countries exists, but remains limited (considering the challenges including its current negative image). Despite these difficulties, the prospects for coopera- tion seems to have been materialized in the last years in some concrete projects, namely linked to defence cooperation. But one (meaning an individual member of the VG) cannot become overly ambitious considering the objectively reality of the harmonization so far achieved, and the resistive effect of national interest on its current possibilities. 


\section{Bibliography}


T.G. Ash, The Puzzle of Central Europe, The New York Review of Books 1999.

H. Bauerová et al., Scénáre budoucího vývoje jednotného trhu EUv kontextu českého predsednictví V4: reforma vnitřniho trhu a možni partneři, Policy Brief, Ministry of For- eign Affairs of the Czech Republic 2019.

J. Bugajski, Visegrads Past, Present, and Future, «Hungarian Review» 2011, No. 3.

H. Gehring, L. Kirchner, Between Common Interests and National Egotism The Role and Potential of the Visegrád Countries in the EU, KAS International Reports 2012, No. 8.

P. Havlíček, 10 Years of Eastern Partnership. From Prague to Brussels and How to Proceed, AMO 2019.

M. Kořan et al., V4 Trust - the Czech Presidency of the Visegrad Group (2015-2016), Think Visegrad Mid-Term Review, February 2016, https://think.visegradfund.org/wp-content/ uploads/Think-Visegrad_Czech-V4-Presidency-Mid-term-review.pdf (23.12.2019).

M. Kořan, The Visegrad Cooperation, Poland, Slovakia and Austria in Czech Foreign Policy, [in:] M. Kořan, (ed.), Czech Foreign Policy in 2007-2009: An Analysis, Prague: Institute of International Relations 2010.

A. Lazar, Post-EU-Accession Visegrad Cooperation - Results, Rhetoric, Prospects, Biztpol Affairs, 2014.

J. Nad', I. Gyarmati, T. Szatkowski, L. Frank, V4 Cooperation and Coordination in Defence and Security, «Defence and Strategy» 2010, No. 2.

M. Schmelzer, Germany and the V4: A Superficial Relationship?, V4 Revue, Prague, Euro- peum, 2012.

A. Schmidt, Friends forever? The Role of the Visegrad Group and European Integration, «Politics in Central Europe» 2016, No. 3.

T. Strážay, Neither beautiful nor ugly, but functional: a pragmatic view on the Visegrad Group, «Contemporary European Studies» 2014, No. 2.

T. Strážay, Visegrád-Arrival, Survival, Revival, Bratislava: International Visegrád Fund, 2011, http://www.visegradgroup.eu/documents/bibliography/visegradarrival-survival-120628 (23.12.2019). 